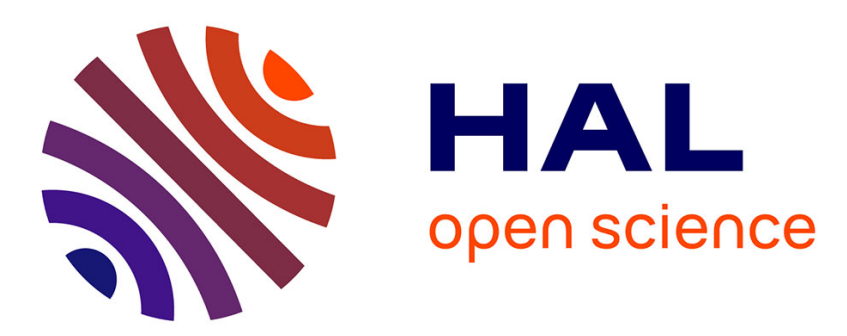

\title{
Microeconomic degrowth: The case of Community Supported Agriculture
}

Nhu Tuyên Lê, Marjolijn Bloemmen, Roxana Bobulescu, Claudio Vitari

\section{To cite this version:}

Nhu Tuyên Lê, Marjolijn Bloemmen, Roxana Bobulescu, Claudio Vitari. Microeconomic degrowth: The case of Community Supported Agriculture. Ecological Economics, 2015, 112, pp.110 - 115. 10.1016/j.ecolecon.2015.02.013 . halshs-01923276

\section{HAL Id: halshs-01923276 https://shs.hal.science/halshs-01923276}

Submitted on 17 Nov 2018

HAL is a multi-disciplinary open access archive for the deposit and dissemination of scientific research documents, whether they are published or not. The documents may come from teaching and research institutions in France or abroad, or from public or private research centers.
L'archive ouverte pluridisciplinaire HAL, est destinée au dépôt et à la diffusion de documents scientifiques de niveau recherche, publiés ou non, émanant des établissements d'enseignement et de recherche français ou étrangers, des laboratoires publics ou privés. 


\title{
Microeconomic degrowth: the case of Community Supported
}

\section{Agriculture}

\section{Authors}

\section{Marjolijn Bloemmen, Roxana Bobulescu, Nhu Tuyen Le, Claudio Vitari}

\begin{abstract}
:
In this paper, we attempt to build a new microeconomic approach that could be considered as a basis of the degrowth macroeconomic view. As degrowth is a critique of the dominant macroeconomic model of the endless search for economic growth, its microeconomic foundations can be built by searching a relevant grass-root economic initiative to theorise. Our approach is based upon the case study research of a self-harvesting Community Supported Agriculture in Belgium. The mainstream microeconomic model is based on the well-known Homo economicus assumption of individual self-interest and competitive behaviour. By contrast, our model is based on a holistic approach of producers and consumers, based upon trust, cooperation and ecologically responsible behaviours. This contribution participates to the flourishing literature on degrowth in Ecological Economics. We begin by reviewing the debate on degrowth and economic behaviour. We discuss the case study and its accounting expression that departs from the capitalist profit-seeking model. We conclude by explaining the limits and challenges of our model that implements degrowth on a small scale and in a capitalist environment.
\end{abstract}


Keywords: sustainable degrowth, microeconomic degrowth, Homo economicus, Community Supported Agriculture, accounting.

\section{Introduction}

The current economic crisis and rising concerns about environmental degradation, pressure on natural resources and climate change nourish post-growth debates in Ecological Economics. These debates gained momentum with the raising mistrust in the capacity of political institutions to tackle these problems whilst continuing to promote growth of GDP. The emerging economies are currently raising their production and consumption in order to catch up with the Western living standards thus adding a lot of pressure on resources and endangering the sustainability of the dominant economic model.

Economic growth is the dogma of mainstream macroeconomics. All economic policies are designed to foster growth on a global scale and at an accelerating pace. Our economic system is built upon growth and cannot function without it: either demand or supply-side policies focus on growth as an inescapable solution to unemployment and debt crisis. The opposite of growth is recession, with increasing unemployment and a deterioration of living conditions.

But standard macroeconomics ignores the natural reality, the physical conditions of life as the entropy law and the resulting limits to growth. 
Pioneering scholars like Georgescu-Roegen $(1971,1975)$ anticipated the problems that economies are facing today and recommended degrowth as a concerted reduction in production and consumption.

But degrowth is not recession, it is not a GDP reduction in the current system like the austerity economic policy (Kallis, 2011), but a complete transformation of our economies. The 2000s were very productive in terms of research on degrowth (Daly, 2010; Jackson, 2008; Kallis, 2011; Kallis et al., 2009; Kerschner, 2010; Martinez-Alier, 2009; van den Bergh and Kallis, 2012; Victor, 2008...). These different scholars share a common positive view of degrowth as an opportunity to replace material abundance by a better quality of life with stronger social, local and natural connections (Odum, 2008). They also share a large, holistic, systemic approach that can be considered a macroeconomic degrowth project (see Martinez-Alier et al. 2010).

For the moment, the degrowth project lacks theorisation at the microeconomic level and this paper intends to contribute to fill this gap through the analysis of a grassroots initiative, favouring an organic worldview cutting with the mechanic, top-down management (Ingebrigtsen, Jakobsen, 2012).

The development of a self-harvest Community Supported Agriculture (CSA) in Belgium is the case study that serves as a starting point for theory building (Yin, 2014). CSAs are grass-root worldwide initiatives in various forms, in many different contexts (see Urgenci, 2014).

Section 2 defines the conceptual background of the paper by focusing on the degrowth literature, on the holistic view of human beings and a 
revisited critique of mainstream economic assumption of Homo economicus. Section 3 presents our research method of case study theory building. Section 4 offers a description of the CSA case study. Section 5 discusses the case, developing our view on non-material, non-monetary sources of wellbeing. We conclude, in Section 6, on the challenges and implications of our model.

\section{Literature review}

Continuing the pioneering work of Nicolas Georgescu-Roegen (1971), many contributions, in the ecological economics field, deal with the desirability and feasibility of a degrowth transition in our economies. Some scholars propose a sustainable degrowth path called "Socially sustainable economic degrowth" (SSED) (Martinez-Alier et al., 2010) in reaction to the "sustainable development" paradigm that has dominated over the past two decades. Following Daly and Martinez-Alier, Kallis defined degrowth as "a socially sustainable and equitable reduction (and eventually stabilisation) of society's throughput. Throughput refers to the materials and energy a society extracts, processes, transports and distributes, to consume and return back to the environment as waste." (Kallis, 2011: 874). It is important to emphasise the fact that SSED is a grounded theory, because emerging social movements, practices, experiences, collectives and networks call for conceptualisation. The "Nowtopias" (Carlsson, 2008) inspire academic research (Kallis et al., 
2012). Reciprocally, research and theorising foster social change and contribute to the convergence of many grass-roots social and environmental movements. Academic research would thus provide an institutional strategy for degrowth, especially in times of crisis (MartinezAlier et al., 2010).

The SSED thinkers are concerned with a reframing of our Western economies towards "less material abundance and consumption" (Kallis et al., 2012: 3) in order to "create a different system where expansion will no longer be a necessity and where economic rationality and goals of efficiency and maximisation will not dominate all other social rationalities and goals." (Kallis, 2011: 875). According to Kallis, the sustainable degrowth model should be a bottom-up social construct (Kallis, 2011).

Van den Bergh (2011) criticised "radical degrowth" (an oversimplification according to Kallis, 2011) because of its belief (especially in connection to the consumption behaviour) that voluntary, bottom-up solutions are efficient in scaling-down the economy. Van den Bergh considers that these degrowth grassroots initiatives ignore modern insights in psychology and behavioural economics.

Bina and Vaz (2011) suggest that the debates on the meaning of growth need a holistic understanding of human beings. According to these authors, it is urgent to revisit the concept of an economic actor as the very basis of economic theory and practice. Human beings feel good when they develop helpful, cooperative and altruistic behaviour (Batson et al. 2002 ; Post, 2005 ; Rilling et al. 2002). 
The neoclassical economic theory assumes that the Homo economicus is a « narrow self» (Bina and Vaz, 2011). The standard microeconomic approach is based upon the reductionist vision of human beings as individualistic, egoistic, competitive and profit and utility maximisers (see Bina and Vaz 2011, Table 1 p. 172). We need to criticise and reconceptualise the Homo economicus.

An important critique of the standard microeconomic behavioural assumptions was made by the "Revue du Mauss" (Anti-Utilitarist movement in social sciences), founded in 1981 by French sociologist and economist Alain Caillé $(2003,2007)$, an admirer of Marcel Mauss and Karl Polanyi. The anti-utilitarian approach gathers social scientists and asserts that self-interest is only one of the four main reasons for action, together with empathy, obligation and freedom-creativity (Caillé, 2003, 2007).

Ecological economists attempt to redefine the economic actor from a « holistic » perspective (Siebenhüner, 2000). The «Special Issue on The Human Actor in Ecological-Economic Models » (Janssen and Jager, 2000) initiated the research and debate around the homo economicus concept and recent papers intended to foster an alternative view to the standard microeconomic agent (Ingebrigtsen, Jakobsen, 2009; Murtaza, 2011 ; Pelletier, 2010; Waring, 2010). In experimental and behavioural economics, Gintis (2000) used game theory to demonstrate that human beings are strong reciprocators and that altruism is the most contagious behaviour. Even if reciprocators represent a tiny proportion of a population, it can be sufficient to preserve a cooperative behaviour during hard times (Gintis et al., 2003). Three concepts of a holistic economic 
actor were explored: 'homo sustinens' (Siebenhüner, 2000), 'homo politicus' (Faber et al. 2002) and 'homo ecologicus' (Becker, 2006). 'Homo sustinens' is a social being whose characteristics are: altruism, cooperation, communication, and moral responsibility for future generations in a long-term, sustainable perspective. 'Homo politicus' holds human values, strives for justice and acts ethically. 'Homo ecologicus' relates to nature in a sympathetic and respectful manner. In these views, human beings relate to each other and to nature as reciprocators, in a non-utilitarian, non-instrumental manner. They are no longer considered as separated and in competition to defend their selfinterest. The notion of community is a meaningful alternative to individualistic behaviour (Becker, 2006; Bina and Vaz 2011; Murtaza, 2011; Siebenhüner, 2000).

As happiness and welfare are only partly obtained through material pursuits (Frey, 2008; Layard, 2005), human beings develop non-material sources of wellbeing, like beauty and spirituality. Furthermore, ideological beliefs of Ecological Economics include explicit ethical positions and the recognition that "there are more meaningful aspirations for human existence than hedonism" (Spash, 2012: 45).

\section{Methodology}

Since our exploratory theory-building research focuses on a contemporary phenomenon in its real-world context, we chose the case 
study method (Yin, 2014). Its advantage is to benefit from an extensive and "in-depth" description of a social phenomenon.

We chose the CSA experience for three reasons. The first is that its practices and objectives imply a downscaling of economic activity and an increase in the quality of life compatible with a degrowth perspective. The second is the opportunity to do a direct and participant observation. The third is that the CSA is quite stable in terms of mission and objectives.

Among the six main sources of evidence (see Yin, 2014), we triangulated evidence by gathering contemporary documentation, archival records, interviews, direct observations and participant observation. One of the coauthors invested in training programs to get involved in vivo with experiences on the field. We carried out semi-structured interviews with the CSA members. We also visited the CSA farm for 3 consecutive years and several times a year (direct and participant observation). We followed the development of the CSA network indirectly via their emailing list and joined several yearly CSA-network conferences (documentation). We obtained account information from one year (archival records).

\section{Case Study: the CSA}

We selected a Belgian self-harvest CSA, producing organic vegetables in a peri-urban context. The case does not represent all the CSA initiatives, but only the self-harvesting CSAs with an outspoken form of risk-sharing. In practice, many other forms of CSAs exist. 
In this particular initiative one producer/farmer sells all his/her produce to a community of consumers. At the beginning of the growing season the producer estimates the total amount of vegetables that he/she can produce. He/she divides this total amount in a number of so-called "shares of harvest", which are sold to the community of consumers. All the harvesting of the produce is delegated to the consumers, who come and pick the share they paid for when this suits them. The farmland is accessible 24 hours a day, 7 days a week.

\subsection{The farmer}

The CSA produces a large variety of tasty and healthy organic vegetables to satisfy the needs of a selected community of consumers. The entire produce is sold to this community and thus shared by the members of this community. The price paid for each share covers the real cost of the production: consumables, depreciation, financial returns and remunerations are summed up and divided by the number of shares. The volume of vegetables per share is indicative: the farmer estimates the volume per vegetable required for fresh consumption (thus excluding the production of large volumes for conserved food) and he/she puts into place this production volume. Depending on weather conditions and other physical stress (vegetable pests, diseases, pollutions) and the health of the farmer, the volume produced can be smaller or larger than the 
estimated volume. The price for a share is independent of this produced volume: thus the consumers carry the production risk.

The economic objective of the farmer is to balance total costs and total revenues, rather than to produce a margin between the two. Thus he/she negotiates his/her remuneration (and not his/her profit) with the community of consumers. To assure the best price/quality ratio, the farmer does not use expensive heated greenhouses and labour-intensive production methods. The real cost of the (sustainable) production is known. By reducing the profit to zero, the consumers are assured of the best price for their high quality food.

In the social sphere the aim of the CSA is the enjoyment of life through conviviality. For the consumers, the conviviality consists in regaining access to farmland, and being able to spend leisure time in a green environment with other people during harvesting and parties. For the farmer, conviviality consists of being able to work in good conditions in terms of work quantity (he delegates the harvesting, which is a very physical and repetitive task that accounts for at least $50 \%$ of the total work load) and work quality (by delegating the harvest, the farmer saves time to be able to research and innovate his agronomy). The collective accomplishment resides in the local, organic and fair production of high quality vegetables in pleasant conditions for all, while respecting the natural carrying capacity of the land. Furthermore the farm acts as a catalyst for community building and knowledge transfer. 
In the natural sphere the aim of the CSA is the protection, renewal, and regeneration of environmental quality and natural resources. The first is assured by agronomical practices such as: the abolition of synthetic pesticides, herbicides, fungicides and fertilisers, which contaminate the produce and pollute ground water through leaching; or the plantation of hedges and trees at the perimeter of the farmland which increase biodiversity in the farm. Other practices such as no-till and mulching assure the protection and regeneration of natural soil fertility on the farm. The investments in soil fertility and biodiversity assure the preservation of the invested capital in the land by the farmer over the long-term. The farm produces local varieties of seasonal vegetables only, which means that the plants will not have to endure unnecessary growing stress. In this way the farm respects natural rhythms and metabolisms. If crop rotation requires that a certain crop cannot be cultivated a particular year, the farmer will not offer this crop.

\subsection{The community of consumers}

The farmer invites consumers to the farm for volunteer work, training activities and parties. As in agriculture, law generally tolerates the help of family members - all other persons present at the farm are suspected of doing undeclared work. Since the farmer of the CSA collaborates with consumers who are not related to him by family ties, the creation of a special association was necessary to be able to delegate the harvesting to 
consumers and to justify the presence of the consumers on the farmland. The legal status of a self-harvest CSA thus consists of two juridical persons: a farmer and an association.

The number of consumers in the CSA is stable over time (with a $20 \%$ turnover rate), and is based on the maximum production volume of a fulltime workforce of the farmer, the available spare-time of the consumers to come to harvest, and the carrying capacity of the natural environment such as soil fertility, and the optimal use of the available natural resources such as water and sun.

When new customers want to join the community but would exceed the production volume of the farmer, he puts these consumers on a waiting list to avoid resource over-exploitation and work over-load. Once optimal production levels are achieved the farmer neither invests in new land nor hires a waged workforce to increase productivity. However, the farmer helps other entrepreneurs to establish their own CSAs outside the boundaries of his own CSA.

\subsection{Co-production and risk sharing}

The self-harvest CSA was co-conceived by a small group of consumers and the farmer. The social contract between farmer and consumer consists of a yearly invoice for the harvest share, a description of the house rules on the website and a black board on the farmland stating the maximum quantities of vegetables per share. In a yearly meeting with a 
delegation of the consumers, the farmer explains the accountancy, reflects on the production season, anticipates the following season, explains required additional investments and negotiates his remuneration. In addition, the farmer pays a membership fee to the association, which justifies the presence of the consumers on his farmland. This association has a charter in which the objectives of the association are stated: collaboration with farmers to facilitate consumers to re-establish links with nature and food production.

The main actors of the self-harvest CSA are the farmer and the consumers. They organize production and revenue allocation in a participative manner. The farmer receives a fixed and decent remuneration for working full-time over the civil year, and the consumers agree with the amount at the beginning of the season. The farmer defines the production plan at the beginning of the season: the expected quantities, selection of varieties, the seeding, planting, and harvesting times. To satisfy the demand of the consumers, the farmer pays the maximum attention to high quality products, using a production process that is both meaningful and adapted to human needs and customer skills. The farmer coordinates the participation of the consumers on the farm and launches the self-harvesting activities. The major investment of 1.5 ha of land was made by the farmer, without public subsidies.

The consumers self-harvest the vegetables for their family food needs and visit the farm once every 10 days on average, which entails the consumers' geographical proximity - finding the farm close to their work or home. There is no fixed and imposed vegetable basket content by the 
producer on the consumer. Consumers are free to self-harvest produce based on their needs and preferences, for example in terms of vegetable calibres or varieties. With regard to quantity, the deal is to never pick more vegetables than the consumer will actually eat fresh. Food conservation is agreed upon only in case of over-production. Consumers are invited to participate in (minor) investments. Together, the farmer and consumers define the training sessions and the parties. This transmission of knowledge and skills aims to render consumers more autonomous, not only to facilitate the self-harvesting, but also as citizens in general, reappropriating the production of their food.

The limited size of the CSA initiative facilitates mental proximity, trust and the willingness to share production risk with the farmer. This proximity makes labels, certifications or trademarks redundant. However, this self-harvest CSA chose to certify 'organic produce' to create solidarity and collaboration amongst producers.

\section{Discussion}

In a microeconomic model, producer and consumer behaviours are guided by their respective economic objectives. What happens in the degrowth perspective? How does this modify their goals and satisfaction? How do they interact?

The present case study can be seen as a transition model between the capitalist economy (in which it is emerged) and the degrowth society. The microeconomic degrowth model designates the group of producers and 
consumers forming a community on a local basis. Many actors (public and private) may intervene but for the purpose of the paper we focus on the producer and consumer categories.

Our microeconomic degrowth model does not oppose producers and consumers as "homo economicus" seeking their self-interest. The members of the CSA cannot be considered Homo economicus as in mainstream neoclassical economics. Their production and consumption behaviours are not based upon interest-seeking, self-centred behaviour. A more holistic understanding of human beings (Bina and Vaz, 2011) is needed in the case of such grassroots initiatives. Our observations of dominant trust, cooperation and self-giving attitudes corroborate many studies in the field of neurosciences and behavioural economics (Gintis, 2000).

\subsection{The holistic approach of the producer}

His/her primary goal is the enjoyment of life. Production is aimed at satisfying consumers' needs, and value creation fulfils this "enjoyment of life" for both producer and consumer. Their relationship is direct (non market-biased), trusting, and convivial. They spend time together and discuss their common values, thus combining leisure and working hours. The producer operates on a small scale, thus preserving limited, locally available resources. Overproduction and speculation are avoided by production-on-demand. A fair selling price is established concomitantly. Quantity and quality are negotiated directly with the consumers. 
The producer eventually delegates work to consumers and organises the transmission of required knowledge and skills. He/she also collaborates with other producers, organises exchange moments, and shares his/her experience in a convivial manner, thus departing from self-interest, competitive, "survival-of -the- fittest" behaviour.

The producer-entrepreneur is not the unique risk-bearing person. The risk is shared between the producer and the consumer community in a sustainable manner. For that reason, the risk of failure is reduced and many locally involved actors share the investment. This mental proximity between producers and consumer-investors ideally completes the geographical proximity.

\subsection{The holistic approach of the consumer}

In our model, consumer behaviour embraces simplicity, sobriety and enjoyment of life in a sustainable perspective. Consumers have common goals with producers: they wish to satisfy their needs thus assuring the producer a decent life through an agreement upon the producer's yearly remuneration.

Consumers also increase their leisure time and interact with other consumers in a convivial manner. This leisure time is also an opportunity to access goods and services that inspire their community and contribute to the quality of life (knowledge, discoveries, artistic performances, cultural legacies...). 
The consumers buy local goods and services and pay a price that covers all production costs. The distribution follows the shortest circuits: the direct purchase from the producer, without any intermediaries. Quality is always preferred to quantity.

Of course, consumers are also producers, as they accept paying a fair price for the goods and services purchased. This co-operative behaviour ensures the achievement of social, environmental and economic harmony in the microeconomic sphere.

Table 1 provides a summary of the main characteristics of the holistic microeconomic agent (producer and consumer).

\begin{tabular}{|l|l|}
\hline Economic behaviour & $\begin{array}{l}\text { Non-maximising, non profit-seeking } \\
\text { (profit is a means to an end), } \\
\text { searching quality versus quantity, } \\
\text { small scale }\end{array}$ \\
\hline Social behaviour & Sympathy, conviviality, cooperation, \\
& community participation \\
\hline Natural behaviour & Responsibility towards nature \\
\hline
\end{tabular}

Table 1 The holistic microeconomic agent (Source: the authors)

In our holistic perspective, the producer and the consumer share a common goal and also common views on their relationship and their responsibility towards nature. The economic characteristics that we put on Table 1 derive directly from this convergence of views and interests.

\subsection{The accounting expression}


In this section we introduce one main difference between profit in our model and the capitalist vision of monetary profit. The proposal of a new accounting model or method is beyond the scope of this article.

If the producer reasoned like a capitalist, he/she would maximise profit. But this is not the case in our model. There is a convergence of expectations between the producer and the consumers around the notion of enjoyment of life. The non-monetary part of satisfaction is more important than the monetary one. A non-monetary profit can take the form of participating in a project or increasing one's autonomy by acquiring knowledge or skills.

The double entry bookkeeping mechanism that prevails in our capitalist economies can be adapted to a non-capitalist model like our case study. The accounting double entry bookkeeping of commitments and expectations is adapted and thus transformed into an expression of the reality of CSAs. In the CSA case study there is no novelty in terms of accounting bookkeeping techniques. However, the difference resides in the way the CSA partners mobilize the accounting information in running the CSA. The issue of how to integrate the natural and human aspects into the firm's accounts have been tackled (Elkington, 1997; Rambaud et al., 2013). But issues still remain, such as how to evaluate the natural capital and the human capital in monetary terms, and then to account for them. The ways the natural and human capitals are considered at the origins of the CSA project represent the fundamentals of the project. Any violation of these fundamentals would lead to the rupture of the project. Therefore the financial accounting representation contributes to 
consolidate the viability of the activities within the economic, natural and social spheres. The search for equilibrium between the three spheres economic, social, natural - is the aim of the commitments and expectations equilibrium table (see Table 2). The search for this equilibrium shows that the economic part is not dominant, but has to balance the natural and social commitments upon which the CSA members have agreed.

The model takes into account the visible and invisible resources in its accounting presentation. The information disclosed is not necessary in monetary terms because the ultimate objective is not only to measure the financial profit.

\begin{tabular}{|l|l|l|}
\hline $\begin{array}{l}\text { Sphere } \\
\text { s }\end{array}$ & \multicolumn{1}{|c|}{ Commitments } & \multicolumn{1}{|c|}{ Expectations } \\
\hline $\begin{array}{l}\text { Econom } \\
\text { ic }\end{array}$ & $\begin{array}{l}\text { Commitments on production } \\
\text { consumptions such as raw } \\
\text { materials, property, plant and } \\
\text { equipment depreciation and } \\
\text { other resources or services } \\
\text { for production. } \\
\text { Commitments on the } \\
\text { monetary interests for } \\
\text { creditors. } \\
\text { Commitments on financial } \\
\text { returns for shareholders. }\end{array}$ & $\begin{array}{l}\text { Revenues from operational } \\
\text { activities: sale prices and } \\
\text { quantities are forecast, based on } \\
\text { the original commitments } \\
\text { prescribed in the project. }\end{array}$ \\
\hline Social & $\begin{array}{l}\text { Contractual commitments for } \\
\text { remunerations as counterpart } \\
\text { of competences and labour } \\
\text { force. } \\
\text { Commitments to promote } \\
\text { human development and well- } \\
\text { being. }\end{array}$ & $\begin{array}{l}\text { Revenues (financial and non- } \\
\text { financial) to preserve the social } \\
\text { sphere. }\end{array}$ \\
\hline Natural & $\begin{array}{l}\text { Commitments to respect and } \\
\text { preserve the natural sphere. }\end{array}$ & $\begin{array}{l}\text { Revenues (financial or non- } \\
\text { financial) to preserve the natural } \\
\text { sphere. }\end{array}$ \\
\hline
\end{tabular}


Income $=$ Total Revenues - Total Commitments.

Income is not the objective to attain but an alert system to keep the equilibrium around zero income

Table 2 Commitments and Expectations Equilibrium Table for the CSA model (Source: authors)

Instead of the term 'revenues', we use the term 'expectations', to depict the revenues that each component should receive in return for maintaining the microeconomic equilibrium of the CSA. The financial investments require return on financial terms. Human beings may expect financial remuneration but also the satisfaction of accomplishing a project or a passion, or gaining new knowledge and skills.

In a capitalist income statement the net income bottom line is automatically transferred into shareholders' equity in order to remunerate the business risks that the shareholders are supposed to bear. Risks are integrated as commitments in the income statement. So the bottom line is not destined to compensate shareholders' risks any more. In the end, accounting becomes the forum where the members of the CSA discuss their expectations and their commitments.

The main concern of the producer in our model is how to allow himself and his partners to reach their expectations by accomplishing their commitments. This is the reason why the Commitments and Expectations Equilibrium Table is a holistic representation of the Income Statement where we do not need to convert all the items into monetary units, as we did not try to maximize these bottom lines. The three-sphere income statement must be balanced for the organisation to sustain. 


\subsection{Limits}

A first important limit of our paper is the single case, very small-base and voluntary grassroots initiative. The reader may wonder how these kinds of initiatives could alter the whole economic system. We do not have an answer to this question. The aim of our work is to propose an interpretation of a microeconomic experience that the standard neoclassical tools fall short of explaining. The microeconomic behaviour in a CSA contradicts the main assumptions of the Homo economicus. The farmer and the community of consumers do not act and do not interact in accordance with the economic textbooks, thus requiring new theorisation. A second limit is the difficulty to upscale these practices. Nevertheless, we did not intend to write a normative paper. Our main goal was the identification of bottom-up initiatives that could lead to a deep change towards a sustainable degrowth economy. There is a clear cut dominant view of "system approach". We do not hold all the pieces of the puzzle. Our bottom-up approach is part of an organic worldview (Ingebrigtsen Jakobsen, 2012) in which small beginnings may eventually grow. Many elements can stimulate its growth. In this paper we focus on human behaviour.

A third limit is that egoistical behaviour may endanger the sustainability of the social contract underpinning the CSA. In practice, members of the community can have an incentive to cheat on their fellows. Therefore, our 
view of human behaviour may seem naïve and idealistic. In fact, we found many studies in psychology, neurosciences and economic behaviour showing that economic agents are strong replicators and altruism seems to be the most "contagious" behaviour. Moreover, from an individual perspective, the gains in terms of wellbeing through the non-material enjoyment of life and conviviality may surpass the gains of cheating.

Ingebrigtsen and Jakobsen (2012) used Gidden's concept of "utopian realism" to show that utopias from a neoclassical perspective may be realistic from an ecological economic perspective. We think that the term "utopian realism" can apply to our paper and we hope that it will contribute to the understanding of the interconnectedness between economy, nature and society.

\section{Conclusion}

In this article we focus on a grassroots initiative in the field of self-harvest organic CSA in Belgium. The case study served as a starting point for building a pioneering microeconomic degrowth model. We argue that, in accordance with some SSED thinkers, a sustainable degrowth model should be based upon a bottom-up construct (Kallis, 2011). Our model departs from the standard microeconomic behavioural assumptions of the "narrow" Homo economicus. Following many works in Ecological Economics (Bina, Vaz, 2011; Gintis, 2000; Janssen and Jager, 2000; Ingebrigtsen, Jakobsen, 2009; Murtaza, 2011; Pelletier, 2010; 
Siebenhüner, 2000; Waring, 2010), we adopt a "holistic" perspective of humans.

From our exploratory research of the CSA, we conclude that the actual relationship between the farmer and the community of consumers constitutes a particular form of sustainable degrowth. They co-produce through self-harvesting and they share risk (bad weather or other problems affecting production) in a trustful, cooperative and participative manner.

We formulate some of the characteristics of the holistic microeconomic agent (see Table 1) such as non-maximising, non-profit-seeking, searching quality versus quantity and smallness on a local basis. To these economic features we add some social traits like sympathy, conviviality, cooperation, community participation as well as ecological responsibility, as our holistic agent is also a "Homo ecologicus" (Bina, Vaz, 2011). The original contribution of this model is the acknowledgement of the convergence of goals between the producer and the consumer. This is a clear departure from the mainstream microeconomic model. In an attempt to enrich our reflection and foster further initiatives, we develop a three-sphere (economic, social and natural), non-monetary Income Statement by leveraging conventional double-entry bookkeeping accounting principles. 


\section{Acknowledgements}

We would like to thank the anonymous reviewers for their constructive comments and the farmer, who wishes to remain anonymous, for having provided access to the field. The usual disclaimer applies.

\section{References}

Batson, C., Ahmad, N., 2002. Four Motives for Community Involvement. Journal of Social Issues 58 (3), 429-445.

Becker, C., 2006. The human actor in ecological economics: philosophical approach and research perspectives. Ecological Economics $60,17-23$.

Bina, O., Vaz, S., 2011. Humans, environment and economies: From vicious relationships to virtuous responsibility. Ecological Economics 72, 170-178.

Caillé, A., 2007. Anthropologie du don: le tiers paradigme. Paris, La Découverte.

Caillé, A., 2003. Critique de la raison utilitaire. Paris, La Découverte.

Carlsson, C., 2008. Nowtopia: How Pirate Programmers, Outlaw Bicyclists and vacant-lot Gardeners are Inventing the Future Today. Oakland Ca., AK Press. 
Daly, H.E., 2010. From a failed-growth economy to a steady-state economy. Solutions 1, 37-43.

Elkington, J., 1997. Cannibals with forks: the Triple Bottom Line of the 21st Century Business. Oxford, Capstone.

Faber, B., Petersen, T., Schiller, J., 2002. Homo oeconomicus and homo politicus in Ecological Economics. Ecological Economics 40, 323333.

Frey, B., 2008. Happiness: A Revolution in Economics. MIT Press, Cambridge, MA and London, UK.

Georgescu-Roegen, N., 1971. The Entropy Law and the Economic Process. Harvard University Press, Cambridge, Mass.

Georgescu-Roegen, N., 1975. Energy and Economic Myths. The Southern Economic Journal. 41(3), 347-381.

Gintis, H., Bowles, S., Boyd, R., Fehr, E., 2003. Explaining Altruistic Behavior in Humans. Evolution and Human Behavior 24, 153-172.

Gintis, H., 2000. Beyond homo economicus: evidence from experimental economics. Ecological Economics 35, 311-322.

Ingebrigsten, S., Jakobsen, O., 2012. Utopias and realism in ecological economics - Knowledge, understanding and improvisation. Ecological Economics 84, 84-90.

Ingebrigsten, S., Jakobsen, O., 2009. Moral development of the economic actor. Ecological Economics 68, 2777-2784.

Jackson, T., 2009. Prosperity without Growth: Economics for a Finite Planet. London. Earthscan. 
Janssen, M. A., Jager, W., 2000. Special issue the human actor in ecological-economic models. Preface. Ecological Economics 35, 307-310.

Kallis, G., Martinez-Alier, J., Norgaard, R., 2009. Paper assets, real debts. An ecological economic exploration of the global economic crisis. Critical perspectives on international business 5, 14-25.

Kallis, G., 2011. In defence of degrowth. Ecological Economics 70, 873-880.

Kallis, G., Kerschner C., Martinez-Alier, J., 2012. The economics of degrowth. Ecological Economics 84, 172-180.

Kerschner, C., 2010. Economic de-growth vs. steady-state economy. Journal of Cleaner Production 18, 544-551.

Layard, R., 2005. Happiness Lessons from a New Science. Allen Lane - Penguin Books, London.

Martinez-Alier, J., 2009. Socially sustainable economic de-growth. Development and Change 40, 1099-1119.

Martinez-Alier, J., Pascual, U., Vivien, F.-D., Zaccai, E., 2010. Sustainable de-growth: mapping the context, criticism and future prospects of an emergent paradigm. Ecological Economics 69, 1741-1747.

Murtaza, N., 2011. Pursuing self-interest pr self-actualization? From capitalism to a steady-state, wisdom economy. Ecological Economics 70, 577-584.

Odum, H., Odum E., 2008. A Prosperous Way Down. Principles and Policies. University Press of Colorado.

Pelletier, N., 2010. Environmental sustainability as the first principle of distributive justice: towards an ecological communitarian 
normative foundation for ecological economics. Ecological Economics 69, 1887-1894.

Post, S., 2005. Altruism, Happiness and Health: It's Good to Be Good. International Journal of Behavioral Medicine 12(2), 66-77.

Rambaud, A., Richard, J., 2014. The Triple Depreciation Line (TDL) instead of the Triple Bottom Line (TBL): towards a genuine integrated reporting. Dossier thématique ${ }^{\circ} 8$. Compta-Durable, Paris.

Rilling, J., Gutman, D., Zeh, T., Pagnoni, G., Berns, G., Kilts, C., 2002. A Neural Basis for Social Cooperation. Neuron 35(2), 395-405.

Siebenhüner, B., 2000. Homo sustinens - towards a new conception of humans for the science of sustainability. Ecological Economics 32, 1525.

Spash, C., 2012. New foundations for ecological economics. Ecological Economics 77, 36-47.

Van den Bergh, J., 2011. Environment versus growth. A criticism of “degrowth" and a plea for "agrowth". Ecological Economics 70, 881-890.

Van den Bergh, J., Kallis, G., 2012, Growth, a-growth and de-growth to stay within planetary boundaries? Journal of Economic Issues 49(4), 909-919.

Victor, P. A., 2008. Managing Without Growth: Slower By Design, Not Disaster. Edward Elgar, Cheltenham, UK; Northampton, MA.

Waring, T.M., 2010. New evolutionary foundations: theoretical requirements for a science of sustainability. Ecological Economics 69, 718-730. 
Yin, R., 2014. Case Study Research. Design and Methods. Sage Publications Inc., California. 